\title{
Analysis of Influencing Factors on the Development of CW Disposal Industry Based on DEMATEL Method
}

\author{
CHEN Qijun, CHEN Yizhong
}

(School of Management and Engineering, Shandong Jianzhu University, Jinan 250101, China)

qijunc@126.com, 1076993027@qq.com

\section{Key words: CW Disposal; DEMATEL Model; Index Factors; Industrial Development}

Abstract: The Construction Waste $(\mathrm{CW})$ treatment resources have increasingly aroused concern because the CW disposal industry involves many subjects, including the unstable supply of raw materials and sluggish sales of recycled products and other characteristics, and industrial development hasn't yet reached the ideal state. Based on the whole industry chain from the 4 dimensions of the government departments, construction enterprises, CW disposal enterprises, and recycled product users, the paper puts forward several factors affecting industrial development of $\mathrm{CW}$ disposal, and uses the quantitative application of DEMATEL method to analyze the interaction among various factors and causality. According to analysis results, resource consciousness of construction enterprise, pricing rationality of recycled products, implementation of the supporting policy, resource consciousness of CW disposal enterprises, proper project construction site, resources awareness of government and sales of recycled products sales are the key factors affecting the industrial development. Finally, the paper puts forward reasonable suggestions for the key factors in order to promote the development of building solid waste resource processing industry.

\section{Introduction}

With the continuous improvement of people's living standards, the requirements for housing standards are getting higher and higher. It is necessary to improve the city functions, and construct and reconstruct a lot of infrastructure and high standards community. In addition, the "national new urbanization plan (2014-2020)" proposed that in order to improve the urbanization rate to about $60 \%$, it is necessary to make rural demolition and reconstruction to change the originally scattered, chaotic, and poor environment, which will inevitably produce a large number of CW. China wants to build a green, coordinated and sustainable society, so a great number of $\mathrm{CW}$ disposal is an urgent problem to be solved. The government has already realized the urgent problem and made great efforts to solve it. Ministry of Housing and Urban-Rural Development puts forward a program named Green Building Materials Production and Application Action to emphasize CW treatment and recycling. It could strengthen the production technology of recycled building materials in order to improve the amount of $\mathrm{CW}$ and product quality. China's CW recycling industry is still in the primary stage of development. There are two reasons for the present situation. Firstly, the State hasn't introduced the corresponding mandatory laws and operational policies for CW disposal. Secondly, government, enterprises and the public have a weak sense of resource, which results in the fact that CW disposal industry chain couldn't be recycled. Therefore, in the face of the development status of the $\mathrm{CW}$ disposal industry chains, this paper analyzes the relationship between the development factors of the industrial chain and makes a quantitative analysis. Finally, effective suggestions are put forward to promote the development of CW disposal industry. 


\section{Research Status of CW Disposal Industry Development}

At present, many experts and scholars have already carried out $\mathrm{CW}$ recycling research. Based on the amount of $\mathrm{CW}$, Kofoworola concludes that the amounts of $\mathrm{CW}$ production in the residential and non-residential construction unit area were $21.38 \mathrm{~kg} / \mathrm{m}^{2}$ and $18.99 \mathrm{~kg} / \mathrm{m}^{2}$, and establishes a CW database by using long-term statistical research [1]. Rui Cunha uses DEA to study all the CW disposal enterprises in Portugal. He finds that many enterprises aren't efficient in management. The main reason for the poor circulation of $\mathrm{CW}$ disposal industry chain is lack of relevant incentive policies of the government ${ }^{[2]}$. Xavier Ruan sets up an economic model by collecting information on Irish $\mathrm{CW}$, suggesting collecting resource taxes on $\mathrm{CW}$ producers and subsidizing the consumers using recycled products to promote $\mathrm{CW}$ recycling ${ }^{[3]}$.Although domestic research is later than the abroad research on this issue, experts and scholars have made great progress on the actual conditions of our country. M.M. Hu takes the current situation of CW resources in Chongqing as an example. Through the field visiting and researching, four typical waste disposal methods are cost-calculated. It is found that the resource processing cost is the lowest in reality, which is expected to be the future CW disposal direction [4]. D.D. Qi constructs the success factor identification model of $\mathrm{CW}$ disposal industry, and identifies ten successful factors of CW disposal utilization. Through the questionnaire survey, the experts conclude that the key success factors are "government resource awareness", and "policy support and use of recycled products". Then they analyze these five key success factors for the decision-making departments of government to provide basis $^{[5]}$.

Currently, experts and scholars focus on the impact of several factors in the industrial development on the $\mathrm{CW}$ recycling industry research, but these factors are analyzed independently, so the relationship among many influencing factors are not studied. Therefore, there are fewer studies on the influence degree of other factors in industry development. Because the factors affecting the $\mathrm{CW}$ recycling industry are interrelated, the elements of the study can't be isolated. Based on the whole process of CW disposal and the total subjective behavior, this paper uses DEMATEL system factor analysis method to establish the model, analyzes the influence degree and the importance degree of the elements involved in the industry chain to other factors, and finds out the causal factors, results factors and key influencing factors. Finally, reasonable suggestions are put forward to promote the development of CW recycling industrial chain ${ }^{[6]}$.

\section{Establishment of Index System for Development Factors of CW Disposal Industry}

Through literature reading and combing, as well as interviews with relevant experts, the paper summarizes the processing factors that affect industrial development of $\mathrm{CW}$ resources, establishes the index system of influence factors, and lays the foundation for the quantitative analysis of the relationship between the influencing factors. Based on the whole process of $\mathrm{CW}$ disposal and participation in the main behavior, the research sets up 4 dimensions: government departments, construction enterprises, CW disposal enterprises, and recycled product users, and puts up 17 factors including resource awareness of government, improvement of relevant laws and regulations, implementation of the supporting policy and so on. Finally, the index system of influencing factors of CW disposal industry was established. As shown in Table 1. 


\begin{tabular}{|c|c|}
\hline Four dimensions & Influencing factors \\
\hline \multirow{4}{*}{ Government departments } & Resource awareness of government $\mathrm{F}_{1}$ \\
\hline & Improvement of relevant laws and regulations $\mathrm{F}_{2}$ \\
\hline & Implementation of the supporting policy $\mathrm{F}_{3}$ \\
\hline & Perfection of the standard system of $\mathrm{CW}$ recycling $\mathrm{F}_{4}$ \\
\hline \multirow{5}{*}{ Construction enterprises } & Administrative supervision of government law enforcement departments $F_{5}$ \\
\hline & Resource consciousness of construction enterprise $\mathrm{F}_{6}$ \\
\hline & To the resource processing center distance is moderate $\mathrm{F}_{7}$ \\
\hline & The cost of resource processing is reasonable $\mathrm{F}_{8}$ \\
\hline & Getting the preferential policies $\mathrm{F}_{9}$ \\
\hline \multirow{3}{*}{ CW disposal enterprises } & Resource consciousness of $\mathrm{CW}$ disposal enterprises $\mathrm{F}_{10}$ \\
\hline & Proper project construction site $\mathrm{F}_{11}$ \\
\hline & Stable supply of raw materials $F_{12}$ \\
\hline \multirow{5}{*}{ Recycled product users } & Resource processing technology maturity $\mathrm{F}_{13}$ \\
\hline & Sales of recycled products sales $\mathrm{F}_{14}$ \\
\hline & Recognition and acceptance of recycled products $\mathrm{F}_{15}$ \\
\hline & Pricing rationality of recycled products $\mathrm{F}_{16}$ \\
\hline & Government incentives for the use of recycled products $F_{17}$ \\
\hline
\end{tabular}

Table1 Analysis Index System of Influencing Factors for Development of CW Disposal Industry

\section{Analysis of Influencing Factors Based on DEMATEL Model}

DEMATEL is known as decision-making experiment and evaluation laboratory. It is proposed by the American Bottelle Institute. It uses the matrix tool and the graph theory to analyze the relationship of the system elements, building the direct influence matrix $X$, calculating the normalized matrix $\mathrm{Y}$ and the comprehensive influence matrix $\mathrm{Z}$ through Matlab software. The influencing degree of each factor on other factors and the degree of impact are calculated by the integrated impact matrix. Finally, the researchers get the central degree and the degree of each index factor, and identify the key influencing factors that affect the development of the CW disposal industry ${ }^{[7]}$.

\section{The Analysis of the Influencing Factors Based on the DEMATEL Model is as follows:}

(1) To create a direct impact matrix X. According to the above analysis, the factors affecting the development of $\mathrm{CW}$ disposal industry are shown with $\mathrm{F}_{1}, \mathrm{~F}_{2}, \mathrm{~F}_{3} \cdots \cdots \mathrm{F}_{16}, \mathrm{~F}_{17}$. Assume that the $n$-th order matrix $\mathrm{X}=(F)_{n \times n}$, and interview with experts in the $\mathrm{CW}$ disposal industry and academics. If the factor $\mathrm{F}_{i}$ has a direct effect on $\mathrm{F}_{j}$, the $0,1,2,3,4$ scale system is used 0 : there is no impact, 1: the degree of impact is weak, 2: the degree of impact is general, 3: the impact of a higher degree, 4: a high degree of impact. Then we could invite relevant experts to rate according to the size of the impact, that is, $\mathrm{F}_{i j}=0(1,2,3,4)$. Finally calculate the average of the expert scores, getting a direct impact matrix $\mathrm{X}=\left(F_{i j}\right)_{n \times n}$, as can be seen in the Table 2 


\begin{tabular}{|l|l|l|l|l|l|l|l|l|l|l|l|l|l|l|l|l|l|}
\hline & $\mathrm{F}_{1}$ & $\mathrm{~F}_{2}$ & $\mathrm{~F}_{3}$ & $\mathrm{~F}_{4}$ & $\mathrm{~F}_{5}$ & $\mathrm{~F}_{6}$ & $\mathrm{~F}_{7}$ & $\mathrm{~F}_{8}$ & $\mathrm{~F}_{9}$ & $\mathrm{~F}_{10}$ & $\mathrm{~F}_{11}$ & $\mathrm{~F}_{12}$ & $\mathrm{~F}_{13}$ & $\mathrm{~F}_{14}$ & $\mathrm{~F}_{15}$ & $\mathrm{~F}_{16}$ & $\mathrm{~F}_{17}$ \\
\hline $\mathrm{F}_{1}$ & 0 & 4 & 4 & 3 & 4 & 4 & 2 & 0 & 4 & 4 & 2 & 1 & 0 & 3 & 2 & 2 & 4 \\
\hline $\mathrm{F}_{2}$ & 1 & 0 & 3 & 4 & 3 & 3 & 2 & 3 & 3 & 3 & 2 & 3 & 3 & 3 & 2 & 2 & 2 \\
\hline $\mathrm{F}_{3}$ & 0 & 1 & 0 & 2 & 3 & 3 & 2 & 2 & 4 & 3 & 3 & 3 & 2 & 3 & 2 & 3 & 4 \\
\hline $\mathrm{F}_{4}$ & 1 & 0 & 2 & 0 & 2 & 1 & 1 & 1 & 0 & 2 & 2 & 1 & 3 & 1 & 2 & 1 & 0 \\
\hline $\mathrm{F}_{5}$ & 1 & 1 & 1 & 2 & 0 & 3 & 1 & 1 & 0 & 3 & 2 & 0 & 2 & 0 & 2 & 0 & 1 \\
\hline $\mathrm{F}_{6}$ & 0 & 1 & 1 & 1 & 2 & 0 & 2 & 2 & 2 & 1 & 1 & 2 & 1 & 3 & 1 & 2 & 0 \\
\hline $\mathrm{F}_{7}$ & 0 & 1 & 1 & 0 & 2 & 3 & 0 & 4 & 0 & 0 & 2 & 3 & 0 & 0 & 0 & 3 & 0 \\
\hline $\mathrm{F}_{8}$ & 0 & 0 & 1 & 0 & 0 & 3 & 2 & 0 & 1 & 1 & 1 & 1 & 2 & 0 & 0 & 3 & 2 \\
\hline $\mathrm{F}_{9}$ & 1 & 0 & 0 & 0 & 0 & 4 & 0 & 2 & 0 & 0 & 0 & 3 & 0 & 1 & 2 & 3 & 1 \\
\hline $\mathrm{F}_{10}$ & 1 & 0 & 0 & 0 & 2 & 0 & 1 & 2 & 0 & 0 & 3 & 2 & 4 & 2 & 2 & 1 & 1 \\
\hline $\mathrm{F}_{11}$ & 0 & 0 & 0 & 1 & 2 & 3 & 4 & 3 & 0 & 4 & 0 & 3 & 4 & 2 & 1 & 3 & 1 \\
\hline $\mathrm{F}_{12}$ & 0 & 0 & 0 & 1 & 0 & 0 & 0 & 1 & 0 & 2 & 1 & 0 & 1 & 2 & 1 & 2 & 2 \\
\hline $\mathrm{F}_{13}$ & 0 & 0 & 1 & 2 & 0 & 2 & 0 & 3 & 1 & 2 & 0 & 0 & 0 & 2 & 2 & 3 & 2 \\
\hline $\mathrm{F}_{14}$ & 0 & 0 & 1 & 2 & 0 & 2 & 0 & 0 & 0 & 3 & 2 & 0 & 0 & 0 & 1 & 3 & 2 \\
\hline $\mathrm{F}_{15}$ & 1 & 0 & 1 & 2 & 0 & 2 & 0 & 1 & 0 & 2 & 1 & 0 & 2 & 4 & 0 & 3 & 3 \\
\hline $\mathrm{F}_{16}$ & 0 & 0 & 0 & 0 & 1 & 3 & 1 & 1 & 0 & 2 & 1 & 1 & 1 & 4 & 4 & 0 & 2 \\
\hline $\mathrm{F}_{17}$ & 1 & 0 & 0 & 0 & 0 & 2 & 1 & 0 & 0 & 2 & 0 & 2 & 0 & 3 & 4 & 3 & 0 \\
\hline
\end{tabular}

Table 2 Direct Impact Matrix X

(2) To calculate the normalized matrix Y.Y $=X / \max _{1 \leq i \leq n} \sum_{j=1}^{j=n} x_{i j}=\left[y_{i j}\right]_{n \times n}$

(3) To calculate the comprehensive impact matrix T. It can use Matlab software to calculate the comprehensive impact matrix T, $T=Y(I-Y)^{-1}$ as can be seen in the Table 3 .

\begin{tabular}{|c|c|c|c|c|c|c|c|c|c|c|c|c|c|c|c|c|c|}
\hline & $F_{1}$ & $\mathrm{~F}_{2}$ & $\mathrm{~F}_{3}$ & $\mathrm{~F}_{4}$ & $F_{5}$ & $F_{6}$ & $\mathrm{~F}_{7}$ & $\mathrm{~F}_{8}$ & $F_{9}$ & $\mathrm{~F}_{10}$ & $\mathrm{~F}_{11}$ & $\mathrm{~F}_{12}$ & $\mathrm{~F}_{13}$ & $\mathrm{~F}_{14}$ & $\mathrm{~F}_{15}$ & $\mathrm{~F}_{16}$ & $\mathrm{~F}_{17}$ \\
\hline $\mathrm{F}_{1}$ & 0.023 & 0.108 & 0.129 & 0.122 & 0.149 & 0.193 & 0.100 & 0.078 & 0.127 & 0.186 & 0.115 & 0.098 & 0.077 & 0.167 & 0.133 & 0.150 & 0.162 \\
\hline $\mathrm{F}_{2}$ & 0.040 & 0.015 & 0.102 & 0.136 & 0.116 & 0.161 & 0.094 & 0.138 & 0.098 & 0.155 & 0.107 & 0.130 & 0.137 & 0.155 & 0.121 & 0.145 & 0.114 \\
\hline $\mathrm{F}_{3}$ & 017 & 0.033 & 0.028 & 0.085 & 0.108 & 0.156 & 0.091 & 0.132 & 0.112 & 0.147 & 0.121 & 0.127 & 0.109 & 0.151 & 0.119 & 0.162 & 0.150 \\
\hline $\mathrm{F}_{4}$ & 0.051 & 0.009 & 0.063 & 0.026 & 0.071 & 0.070 & 0.048 & 0.061 & 0.016 & 0.093 & 0.078 & 0.052 & 0.106 & 0.069 & 0.083 & 0.073 & 0.038 \\
\hline $\mathrm{F}_{5}$ & 0.032 & 0.031 & 0.042 & 0.071 & 0.029 & 0.113 & 0.051 & 0.062 & 0.018 & 0.113 & 0.078 & 0.034 & 0.087 & 0.048 & 0.083 & 0.051 & 0.056 \\
\hline$F_{6}$ & 0.008 & 0.029 & 0.039 & 0.046 & 0.068 & 0.050 & 0.069 & 0.082 & 0.059 & 0.067 & 0.054 & 0.077 & 0.056 & 0.110 & 0.060 & 0.100 & 0.036 \\
\hline $\mathrm{F}_{7}$ & 0.005 & 0.029 & 0.036 & 0.019 & 0.067 & 0.111 & 0.027 & 0.123 & 0.015 & 0.040 & 0.072 & 0.097 & 0.033 & 0.041 & 0.032 & 0.112 & 0.031 \\
\hline$F_{8}$ & 0.005 & 0.006 & 0.033 & 0.015 & 0.019 & 0.105 & 0.066 & 0.031 & 0.034 & 0.054 & 0.044 & 0.050 & 0.069 & 0.040 & 0.033 & 0.109 & 0.071 \\
\hline$F_{9}$ & 0.028 & 0.007 & 0.013 & 0.017 & 0.016 & 0.125 & 0.018 & 0.068 & 0.012 & 0.033 & 0.021 & 0.090 & 0.022 & 0.064 & 0.076 & 0.107 & 0.051 \\
\hline $\mathrm{F}_{10}$ & 0.030 & 0.007 & 0.017 & 0.025 & 0.066 & 0.048 & 0.047 & 0.081 & 0.012 & 0.048 & 0.095 & 0.072 & 0.125 & 0.090 & 0.082 & 0.075 & 0.059 \\
\hline$F_{11}$ & 0.010 & 0.009 & 0.021 & 0.050 & 0.076 & 0.128 & 0.121 & 0.120 & 0.015 & 0.145 & 0.042 & 0.108 & 0.137 & 0.105 & 0.072 & 0.135 & 0.066 \\
\hline $\mathrm{F}_{12}$ & 0.006 & 0.002 & 0.008 & 0.034 & 0.012 & 0.026 & 0.014 & 0.040 & 0.005 & 0.073 & 0.040 & 0.016 & 0.044 & 0.075 & 0.048 & 0.076 & 0.067 \\
\hline $\mathrm{F}_{13}$ & 0.008 & 0.005 & 0.037 & 0.064 & 0.020 & 0.088 & 0.022 & 0.100 & 0.035 & 0.084 & 0.028 & 0.027 & 0.032 & 0.091 & 0.084 & 0.115 & 0.078 \\
\hline $\mathrm{F}_{14}$ & 0.008 & 0.004 & 0.033 & 0.061 & 0.022 & 0.079 & 0.022 & 0.027 & 0.009 & 0.103 & 0.071 & 0.026 & 0.032 & 0.041 & 0.057 & 0.105 & 0.071 \\
\hline$F_{15}$ & 0.031 & 0.007 & 0.040 & 0.070 & 0.025 & 0.093 & 0.025 & 0.054 & 0.015 & 0.094 & 0.054 & 0.030 & 0.080 & 0.142 & 0.045 & 0.121 & 0.105 \\
\hline $\mathrm{F}_{16}$ & 0.009 & 0.006 & 0.015 & 0.023 & 0.041 & 0.109 & 0.043 & 0.052 & 0.010 & 0.088 & 0.052 & 0.048 & 0.054 & 0.136 & 0.124 & 0.050 & 0.079 \\
\hline $\mathrm{F}_{17}$ & 0.030 & 0.006 & 0.014 & 0.021 & 0.019 & 0.082 & 0.039 & 0.025 & 0.010 & 0.083 & 0.027 & 0.067 & 0.027 & 0.113 & 0.123 & 0.110 & 0.032 \\
\hline
\end{tabular}

Table 3 Comprehensive Impact Matrix T

(4) According to the element $t_{i j}$ in the comprehensive impact matrix T. It can calculate the 
influence degree $\mathrm{f}_{i}$ of each index factor, the affected degree $\mathrm{e}_{i}$, the center degree $\mathrm{m}_{i}$ and the cause degree of $r_{i}$, as can be seen in the Table 4.The formula for calculating the four indexes is as follows:

$$
\left\{\begin{array}{c}
f_{i}=\sum_{i=1}^{n} t_{i j}(j=1,2 \cdots n) \\
e_{i}=\sum_{j=1}^{n} t_{j i}(i=1,2 \cdots n) \\
m_{i}=a_{i}+b_{i}(i=1,2 \cdots n) \\
r_{i}=a_{i}-b_{i}(i=1,2 \cdots n)
\end{array}\right.
$$

\begin{tabular}{ccccc}
\hline $\begin{array}{c}\text { Influencing } \\
\text { factors } \mathrm{F}_{\mathrm{i}}\end{array}$ & the influence degree $\mathrm{f}_{\mathrm{i}}$ & the affected degree $\mathrm{e}_{\mathrm{i}}$ & the center degree $\mathrm{m}_{\mathrm{i}}$ & the cause degree $\mathrm{r}_{\mathrm{i}}$ \\
\hline $\mathrm{F}_{1}$ & 2.117 & 0.313 & 2.430 & 1.804 \\
$\mathrm{~F}_{2}$ & 1.964 & 0.313 & 2.277 & 1.651 \\
$\mathrm{~F}_{3}$ & 1.848 & 0.670 & 2.518 & 1.178 \\
$\mathrm{~F}_{4}$ & 0.987 & 0.885 & 1.872 & 0.102 \\
$\mathrm{~F}_{5}$ & 0.999 & 0.924 & 1.923 & 0.075 \\
$\mathrm{~F}_{6}$ & 1.010 & 1.737 & 2.747 & -0.727 \\
$\mathrm{~F}_{7}$ & 0.890 & 0.897 & 1.787 & -0.007 \\
$\mathrm{~F}_{8}$ & 0.784 & 1.274 & 2.058 & -0.490 \\
$\mathrm{~F}_{9}$ & 0.768 & 0.602 & 1.370 & 0.166 \\
$\mathrm{~F}_{10}$ & 0.979 & 1.606 & 2.585 & -0.627 \\
$\mathrm{~F}_{11}$ & 1.360 & 1.099 & 2.459 & 0.261 \\
$\mathrm{~F}_{12}$ & 0.586 & 1.149 & 1.735 & -0.563 \\
$\mathrm{~F}_{13}$ & 0.918 & 1.227 & 2.145 & -0.309 \\
$\mathrm{~F}_{14}$ & 0.771 & 1.638 & 2.409 & -0.867 \\
$\mathrm{~F}_{15}$ & 1.031 & 1.375 & 2.406 & -0.344 \\
$\mathrm{~F}_{16}$ & 0.939 & 1.796 & 2.735 & -0.857 \\
$\mathrm{~F}_{17}$ & 0.828 & 1.266 & 2.094 & -0.438 \\
\hline
\end{tabular}

Table 4 Comprehensive Influence of the Factors Affecting the Development of CW Disposal Industry

(5) To draw the causal factor result analysis chart. It can use Matlab software to draw a causeeffect analysis diagram, as shown in Fig. 1.

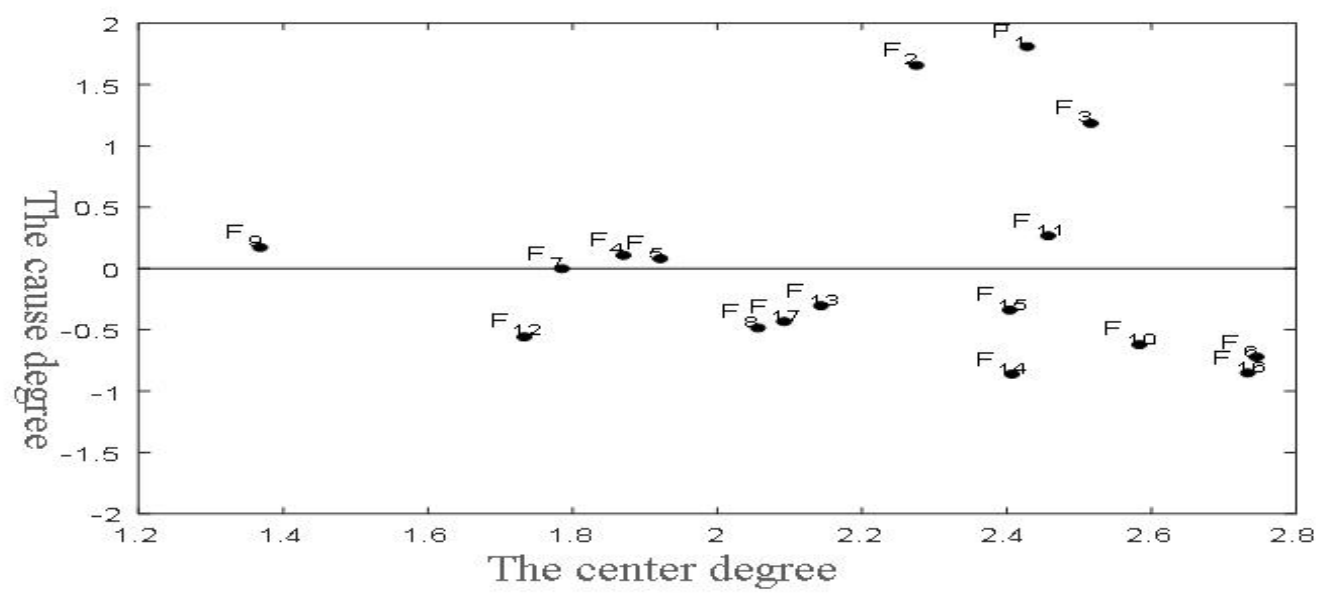

Fig. 1Analysis on the Factors Affecting the Development of CW Disposal Industry - Analysis of Results 


\section{Analysis of Influencing Factors}

(1) To calculate the value based on the cause $r_{i}$. If $r_{i}>0$, it is a causal factor, it indicates that this index has a large impact on other indicators, so it is stable and less susceptible to changes in other indicators. The causal factor is the analysis of the impact of $\mathrm{CW}$ disposal industry development factors that become the primary factors ${ }^{[8]}$. From Table 4 , the relatively strong causal factors can be found: resource awareness of government $F_{1}$, improvement of relevant laws and regulations $F_{2}$, and implementation of the supporting policy $\mathrm{F}_{3}$, etc. These factors are mainly based on the main behavior of the government, and it has a direct impact on the development of the $\mathrm{CW}$ disposal industry and other indicators. As it has public welfare and external economic characteristics, therefore, the government's laws, regulations and policies are needed to guide the development of the industry.

(2) If $r_{i}<0$, it is a result factor, which indicates the index by the impact of other indicators, so these indicators have low stability, and are easily affected by other indicators. From Table 4 the relatively strong result factors can be found: sales of recycled products sales $F_{14}$, pricing rationality of recycled products $F_{16}$, resource consciousness of construction enterprise $F_{6}$, etc. These factors are based on the main business behaviors. They are the main force to promote the development of CW disposal industry. The sale of recycled production is the main result factor, and it is also easily affected by other factors, but it is also important for entire industry chain to develop.

(3) From the center degree $r_{i}$, it can be seen that the key factors influencing the development of the $\mathrm{CW}$ disposal industry are: resource consciousness of construction enterprise $\mathrm{F}_{6}$, pricing rationality of recycled products $\mathrm{F}_{16}$, implementation of the supporting policy $\mathrm{F}_{3}$, resource consciousness of $\mathrm{CW}$ disposal enterprises $F_{10}$, etc. It shows that these indicators are in an important position in the entire industry developing evaluation index system, and have a very strong driving role for other indicators, so they are important factors that affect the development of $\mathrm{CW}$ disposal industry.

\section{Measures to Promote the Development of CW Disposal Industry}

(1) Resource awareness of government plays a central role in promoting industrial development and can guide the government's behavior and formulate measures to deal with the problem. Government should recognize the urgency of $\mathrm{CW}$ recycling and strengthen the $\mathrm{CW}$ of the propaganda efforts to improve the awareness of construction enterprises.

(2) From the generation to recycled products throughout the life cycle, CW can't be separated from the supervision and management of government departments. Government should strengthen the regulation of the generation, transportation and handling of $\mathrm{CW}$, and ensure that all the raw materials could be used for CW disposal industry ${ }^{[9]}$.

(3) When carrying out the project construction site, the resource processing enterprise should do sufficient market research and consider the minimum construction cost and operating cost principle.

(4) Resource processing enterprises should strengthen the market research of recycled products to forecast market demand and analyze product prices. It is also important to improve the price advantage of recycled products to attract more enterprises to use renewable products. Resource processing enterprises also needs to carry on the quality authentication to the recycled product, and eliminate user concerns. 


\section{Conclusion}

This paper analyzes the factors that influence the development of CW disposal industry from four main behaviors of government departments, construction enterprises, CW disposal enterprises and recycled product users. Through the establishment of DEMATEL model, the researchers can conclude the following factors: resource consciousness of construction enterprise $\mathrm{F}_{6}$, pricing rationality of recycled products $\mathrm{F}_{16}$, implementation of the supporting policy $\mathrm{F}_{3}$, resource consciousness of $\mathrm{CW}$ disposal enterprises $\mathrm{F}_{10}$, proper project construction site $\mathrm{F}_{11}$, resource awareness of government $F_{1}$, etc. These factors are the key factors which affect the development of the CW disposal industry. Therefore, reasonable suggestions are put forward for the main influencing factors, with a view to promoting the development of the $\mathrm{CW}$ disposal industry.

\section{References}

[1]K.OF, G. SH: Estimation of construction waste generation and management in Thailand. Waste Management .731-738(2009)

[2] R.C. Marques, N. F. Cruz, P. Carvalho: Assessing and exploring (in) efficiency in Portuguese recycling systems using non-parametric methods Resources. Resources, Conservation and recycling .34-43(2012)

[3] X. Ruan, H. Lenihan, B. O'Regan: A model for assessing the economic viability of construction and demolition waste recycling-the case of Ireland. Resources, Conservation and Recycling .302-320(2006)

[4] M.M .HU, Q. HE, S. Y. SHI, D. D. QI: Evaluation of construction waste management - taking Chongqing as an example. Construction Economics.93-97(2011)

[5] D.D. QI, M.M. HU, S.Y. SHI: Strategic analysis of key success factors of construction waste resource. Architecture Technology .601-604(2012)

[6] C. LIU, Z.YOU: Study on the influencing factors of the development of construction enterprises based on DEMATEL method. Journal of Engineering Management. 6-11(2016)

[7] L.R. Bacudio, M.F.D. Benjamin, R.C.P. Eusebio, S.A.K. Holaysan: Analyzing barriers to implementing industrial symbiosis networks using DEMATEL. Sustainable Production and Consumption .57-65(2016)

[8] J.W. YAN, Z.G. HE, M. PENG, W. LIAO: Research on influencing factors of waste recycling industry in China based on DEMATEL method. Science and Technology Management Research 103-107(2016)

[9] X.S. Huang, B.X. Xu: Laws and regulations on the reduction and utilization of construction waste from the perspective of ecological efficiency. Urban Studies .90-94(2011) 